\title{
ECONOMIC EFFECTIVENESS OF THE CROP-LIVESTOCK INTERACTIONS IN FUNCTION OF ORGANIC PRODUCTION
}

\author{
Zorica Sredojević $^{1}$, Zorica Vasiljević ${ }^{1}$, Mile Peševski ${ }^{2}$ \\ ${ }^{1}$ Faculty of Agriculture, Nemanjina 6, Belgrade-Zemun, Serbia \\ ${ }^{2}$ Faculty of Agricultural Sciences and Food, Ss. Cyril and Methodius University in Skopje, \\ Blvd. Aleksandar Makedonski bb, 1000 Skopje, Republic of Macedonia \\ zokas@agrif.bg.ac.rs
}

\begin{abstract}
The recent research has provided insight into the item whether livestock must be included in the crop farm in order to attain the economic benefits of crop-livestock interactions, particularly those related to soil fertility management. Crop-livestock operations are well suited to the adoption of many alternative practices. Crop rotations using cover crops, such as leguminous hays, are readily suited to livestock operations. These rotations reduce fertilizer and pesticide needs and provide a valuable feed source. Many legumes are quality hay crops. In croplivestock operations, hay crops with a market value ordinarily lower than cash grains have economic value as a portion of farm land in a cover crop. They may provide additional erosion control benefits and allow the planting of feed grains on more suitable land. Manure also becomes a valuable source of soil organic matter, nitrogen and other nutrients such as potassium and phosphorus. Diversified crop-livestock operations also have greater protection against input (feed) and output (animal products) price fluctuations. By different methods of calculations in this paper economic benefits in the interaction of cropping and livestock as well as the effects of the crop rotations on the farm will be analyzed.
\end{abstract}

Key words: crop rotations; livestock; organic production; economical effectiveness

\section{ЕКОНОМСКАТА ЕФИКАСНОСТ НА РАСТИТЕЛНО-СТОЧАРСКАТА ИНТЕРАКЦИЈА ВО ФУНКЦИЈА НА ОРГАНСКОТО ПРОИЗВОДСТВ}

\begin{abstract}
Резултатите од неодамнешното истражување покажаа дека е неопходно говедарството да биде вклучено во производниот процес на фармите за растително производство, за да се постигне економска добивка од растително-сточарската интеракција, а што е делумно поврзано и со управувањето со плодноста на почвата. Растително-сточарското производство исто така е поврзано со усвојување на разни алтернативни начини на работа. Плодоредот, користејќи легуминозни растенија за производство на сено, е тесно поврзан со сточарството. Таквите ротации ја редуцираат употребата на ѓубрива и пестициди и обезбедуваат вреден извор на храна. Многу легуминози даваат квалитетно сено. Во растително-сточарското производство сеното е со пазарна вредност обично пониска од цената на зрното, но тоа има економска вредност како дел од фармското земјиште на кое се одгледуваат растенијата. Растенијата можат да обезбедат дополнителна контрола на ерозијата и да овозможат садење и сеење на прехранбени култури на подобрена почва. Освен тоа, шталското ѓубре станува вреден извор на органска материја, азот и други нутриенти како што се калиум и фосфор. Разновидноста на растително-сточарското производство исто така придонесува за поголема заштита од флуктуацијата на цените на храната (input) и на животинските производи (output). Преку различни пресметковни методи во овој документ се анализирани економските придобивки од интеракцијата на растителното и сточарското производство, како и ефектите од плодоредот на фармата.
\end{abstract}

Клучни зборови: плодоред; сточарство; органско производство; економска ефикасност

\section{INTRODUCTION}

Basic reasons for expansion of organic agriculture could be found in the results of numerous researches which point at an increase of health risk in the case of the food consumption that is coming from intensive conventional production. According to the medical researches' results the health risk has been frequently resulted into the high frequency of disturbances in the newborn infants' 
development and health as well as in the fertility disturbances that have been proved both in the case of human beings and animals. All mentioned items have influenced significant increase of the organic production volume in the course of recent decade. Today in the world there are more than 26 million hectares under organic production. The greatest areas under organic agricultural system are situated in Australia $(11,300,000$ ha), Argentina $(2,899,999 \mathrm{ha})$, Italia $(1,052,002 \mathrm{ha})$ and USA $(930,810 \mathrm{ha})$. The percentage relation of organic production areas and total country areas give a completely different picture, as there are only the European countries in the first 10 countries on the list according to the mentioned indicator, i.e. Liechtenstein (26.4\%), Austria (12.9\%) and Switzerland $(10,27 \%)$. In Europe, the greatest areas in the system of organic production are in Italy, Germany and Great Britain, so those countries represent the most important sector of organic production. In most European countries, around $6 \%$ of cultivable areas are in the organic production system. A trend of organic production development in the countries of Central and Eastern Europe has been recently more and more expressive as well (Czech Republic, Slovakia and Poland).

Agricultural areas in the system of completed organic production in Europe have been increased from 1.5 million hectares in 1995 onto 6.3 million hectares in 2005. In the same period, a number of organic farms have been increased from 50,000 onto 170,000 . In Germany, within organic livestock husbandry there is the greatest percentage of sheep husbandry (8\%), then of cattle fattening $(3.2 \%)$, milking cows $(2.3 \%)$, while only $1 \%$ of poultry and pigs are present in organic systems of husbandry. In advertisement campaigns of the biggest world corporations for production of organic animal products there is present an increasing stress on the fact that products have been produced from the animals grown in conditions of self-sustainable agriculture with the highest standards of welfare and eco-system protection. Today among all organic animal products it is the highest consumption of "organic milk". It can be said that "organic milk" is increasingly present in the supermarkets of most EU countries. The highest production of "organic milk" is present in Denmark (15\%) with planned triple increase. In Austria about $14 \%$ of milk is coming from the farms organized according to the self-sustainable production concept. Production of "organic milk" in the Nordic countries amounts to only $1 \%$ out of the total production. In Switzerland the project of the self-sustainable organic farms has started in 1997 and it included 2,000 cows. One of the limiting factors for wider consumption of such milk is the price, which is by $25-40 \%$ higher than the price of milk produced in commercial production.

In Serbia the system of management by agriculture in organic conditions is regulated by the "Law on organic production and organic products", which is based on four principles such as the health principle (for plants, animals and human beings as an indivisible natural totality), the ecological principle, the principle of righteousness and the principle of care and fostering. Important topics for organic production development are establishment of national certification system as well as protection of national market from the products appearing at the market with synonyms reflecting there is a health-protected food (organic, ecologic, biologic etc.), but without registration and certification as organic production products. In accordance with that, the products from organic agriculture certificated on the basis of the "Law on organic production" have to be marked by the sign "Organic product" and by code of certification organization.

\section{MATERIAL AND METHODS}

On the basis of accounting records data, as well as plan and final calculations and financial reports for particular farms in the plain part of Serbia, it has been established the model of farm that has mixed crop and livestock production character. The farm is oriented towards organic production. Within livestock production it is present the cattle production with orientation onto production of final market products - milk and fattened cattle up to $250 \mathrm{~kg}$ and $450 \mathrm{~kg}$. The basis for the farm size is the cultivable area capacity. According to this indicator there have been determined capacities of other production factors, technical assets, number of the livestock. Consequently, the planned production farm capacities are the following: arable land - 600 ha; buildings - stables; maternity home, calves house and cattle fattening house; trench silo; hay barn; tanks and manure yard; storehouse; garages main building and additional buildings; machines and devices - tractors; combines; ploughs; disc harrow; seedbed tiller; 
sprayer; manure loader and spreader; mixer trailer, milking device, tanks, etc. necessary working machines and devices; labor force - 10 full-time workers for operations in crop growing and livestock husbandry, while 3 full-time workers are planned for management and administration, and if it is necessary some part-time workers will be engaged. All calculations have been done on the basis of the structural unit: milking cow $=1$, female calf up to 4 months $=0.22$, heifer $4-12$ months $=$ 0.22 , heifers $12-22$ months $=0.2$, heifers in calf $=$ 0.20 , fattening cattle up to $250 \mathrm{~kg}=0.66$, fattening cattle up to $450 \mathrm{~kg}=0.66$. Length of breeding utilization is 5 years, the calving rate is $88 \%$, replacement of milking cows is done by own reproduction. The structure of crop production includes the following crops: winter wheat, winter barley, maize-grain, sunflower, soybean, sugar beet, silage maize, lucernes, oil rapeseed, mixture of peas and winter barley. The crops have basically been planned for provision of feed basis for livestock at the farm, while the surplus is planned to be sold at the market.

There have been made direct costing calculations for all production lines present at the farm. Then, by appreciation of appropriate limitations (basic principles of organic production, arable land surfaces, provision of minimal feed quantity, crop rotation conditions), and by utilization of the simplex econometric method for optimization, there has been established an optimal size structure of particular production lines at the farm. The optimal goal was the maximal profit of the farm. For optimal number of livestock heads, it has been projected the quantity of manure production as an input for crop production. In the next step it has been made the crop rotation plan that could give the best utilization of projected manure quantities and as much as possible naturally solved problems of the pest, weed and disease control. In that way it has been elaborated possibility of economically justified interactive linkages between crop and livestock farm production, as one of important condition for organic production.

\section{RESULTS AND DISCUSSION}

In livestock growing in organic production conditions, it usually starts from linkages between crop and livestock production mostly from the standpoint of provision the following items: feed basis, manure as organic fertilizer, quality of livestock feed, healthy animals, appropriate fertility, longevity, productivity. One of important principles of organic production is that basic needs of feed have been provided by own areas ( $\min 80 \%$ ), while the rest quantities could be provided out of the farm. At the same time, in order to manure the fields regularely, it has been planned a number of animals according to the needs for manure production. For the analyzed farm model in this paper, calculative procedure for particular production lines as well as the starting optimization matrix have been avoided due to the limited space. If we use the principles of conventional (intensive) production, it has been calculated that there could be provided from those areas the feed for volume of 263 milking cows, necessary young animals for replacement of the basic herd, as well as 184 fattening cattle heads up to $450 \mathrm{~kg}$. In that case it is necessary to provide quantity of voluminous feed amounting to $1,734,420 \mathrm{n}$.u. as well as $315 \mathrm{t}$ of maize. Necessary quantity of voluminous feed in the case of conventional way of production should be produced on the area of $176 \mathrm{ha}$, as a basic crop, and on the area of 90 ha in the postharvest seeding. For provision of necessary maize quantity, it is needed area of 35 ha. In the case of organic production, at the same arable land of the analyzed farm, it should be produced less volume of voluminous feed by 413,241 n.u., i.e. by about $24 \%$, as well as less quantity of maize for livestock feed by $87.5 \%$ or by $28 \%$ (Table 1 ).

In order to be provided necessary quantity of livestock feed for the appropriate cattle production size even after transition of the farm onto organic production, it should be necessary to increase the area under livestock feed crops. The supposition is that the farmer will keep on with the same size of cattle production amounting to 263 milking cows and 184 fattening cattle heads because of the following: satisfactory productivity (achievement of milking efficiency amounting to 6.000 lit annually), safety of market for produced milk and beef, capability and willingness to deal with cattle production, regular inflow of financial resources; presence of the crops convenient for the soil fertility maintenance (lucernes, silage maize); possibility for livestock feed production even in the postharvest seeding as well as getting higher quantities of solid manure for achievement of satisfactory yields in the organic production conditions. 
Ta ble 1

Animal feed production on the farm in the case of conventional and organic production

\begin{tabular}{|c|c|c|c|c|c|c|c|}
\hline \multirow[t]{2}{*}{ Crop } & \multirow{2}{*}{$\begin{array}{l}\text { Area } \\
\text { (ha) }\end{array}$} & \multicolumn{2}{|c|}{$\begin{array}{l}\text { Conventional } \\
\text { production }\end{array}$} & \multicolumn{2}{|c|}{ Organic production } & \multicolumn{2}{|c|}{ Difference } \\
\hline & & $(\mathrm{t} / \mathrm{ha})$ & Total (n. u.) & $(\mathrm{t} / \mathrm{ha})$ & Total (n. u.) & n. u. & $\%$ \\
\hline Lucerne & 90 & 10 & 439,200 & 9.2 & 404,100 & $-35,100$ & 8 \\
\hline Silage maize & 86 & 35 & 903,000 & 25 & 645,000 & $-258,000$ & 29 \\
\hline Oil rapeseed & 57 & 30 & 268,470 & 21 & 187,929 & $-80,541$ & 30 \\
\hline Peas+w. barley & 33 & 25 & 123,750 & 17 & 84,150 & $-39,600$ & 32 \\
\hline Voluminous livestock feed (total) & & & $1,734,420$ & - & $1,321,179$ & $-413,241$ & 24 \\
\hline Maize & 35 & 9 & $315 \mathrm{t}$ & 6.5 & 227.5 & $-87.5 t$ & 28 \\
\hline
\end{tabular}

Economically the most appropriate and optimal crop production structure, with previously present size of cattle production, has been determined on the basis of the input-output parameters in organic production as well as by the new optimizing procedure. Necessary voluminous livestock feed could be provided by production of silage maize on the area of 139 ha, increased by 53 ha $(62 \%)$, instead of given up sunflower production (30 ha) as well as decreased maize production by 23 ha $(24 \%)$. By provision of the maize for livestock feed, the market quantity has been decreased by $383 \mathrm{t}$ or $72 \%$ compared to the conventional way of production. For maintenance of the soil production ability in the case of organic way of production, the leguminous crops as lucerne and soybean are of great importance, with a proportionally high share $(20 \%)$ in the seeding structure. For particular quantities, disassembling of dry organic substance in the course of year per hectare of arable land could be calculated from the following structure (Ruthenberg, H., 1958): in the case of root crops share up to $15 \%$ it is $2 \mathrm{t}$ of organic substance; up to $25 \%$ it is $3 \mathrm{t}$ of substance and for share up to $35 \%$ it is $4 \mathrm{t}$ of substance. Manuring by solid manure compared to the liquid one has numerous advantages and some of them are the following: it improves physical, chemical and microbiological characteristics of soil; it does not contains harmful germs which are transferring onto agricultural products; it does not pollute water, air and agricultural soil; its transport and spreading on the soil is much easier and efficient. In the analyzed farm model it has been supposed that in the case of the organic production sub-model there is no application of fertilizer, except in the case of sugar beet, whereas it is projected urea $46 \%$ with 0.3 $\mathrm{t} / \mathrm{ha}$, which does cause some ecological problem. From both ecological point of view and more realistic evaluation nutrient contents, one of the satisfactory solutions represents an assessment of manure production given by Tietjen and Vetter (1972), which is based on an average normative of $4.6 \%$ for the solid phase and $3.3 \%$ for the liquid one, out of average animal weight per day (Sredojević, 2000). On the basis of an assessment for quantity per day, annual manure production per particular categories of cattle at the farm has been calculated (Table 2).

Ta b 1 e 2

Quantity of manure per head of particular cattle category on the farm

\begin{tabular}{|c|c|c|c|c|c|c|c|c|}
\hline \multirow[t]{2}{*}{ Category of cattle } & \multirow{2}{*}{$\begin{array}{l}\text { Weight of } \\
\text { animal head } \\
\text { (kg l. w.) }\end{array}$} & \multirow{2}{*}{$\begin{array}{l}\text { Number of days } \\
\text { in the category }\end{array}$} & \multicolumn{2}{|c|}{ Solid phase } & \multicolumn{2}{|c|}{ Liquid phase } & \multicolumn{2}{|c|}{ Total } \\
\hline & & & $\begin{array}{c}\text { Per day }{ }^{\mathrm{a})} \\
(\mathrm{kg})\end{array}$ & $\begin{array}{c}\text { Annually } \\
(\mathrm{t})\end{array}$ & $\begin{array}{c}\text { Per day }{ }^{\mathrm{a})} \\
(\mathrm{kg})\end{array}$ & $\begin{array}{c}\text { Annually } \\
\text { (t) }\end{array}$ & $\begin{array}{c}\text { Per day }{ }^{\text {a) }} \\
(\mathrm{kg})\end{array}$ & $\begin{array}{c}\text { Annually } \\
(\mathrm{t})\end{array}$ \\
\hline Milking cow & 620 & 365 & 28.52 & 10.41 & 20.46 & 7.47 & 48.98 & 17.88 \\
\hline Heifer in calf & 450 & 285 & $20.70^{*}$ & $5.90 * *$ & 14.85 & 4.23 & 35.55 & 10.13 \\
\hline Heifer $12-22$ months & 325 & 122 & 14.95 & 1.82 & 10.72 & 1.31 & 25.67 & 3.13 \\
\hline Heifer 4-12 months & 210 & 243 & 9.66 & 2.35 & 6.93 & 1.68 & 16.59 & 4.03 \\
\hline Female calf up to 4 months & 84 & 122 & 3.86 & 0.47 & 6.64 & 0.81 & 10.50 & 1.28 \\
\hline Fatt. cattle up to $250 \mathrm{~kg}$ & 200 & 105 & 9.20 & 0.97 & 6.60 & 0.69 & 15.80 & 1.66 \\
\hline Fatt. cattle up to $450 \mathrm{~kg}$ & 350 & 178 & 16.10 & 2.87 & 11.55 & 2.06 & 27.65 & 4.92 \\
\hline
\end{tabular}

$* 20.70 \mathrm{~kg}=4.60 \% \times 450 \mathrm{~kg} ; * * 5.90 \mathrm{t}$ annually $=(20.70 \mathrm{~kg} \times 285$ days $): 1000 \mathrm{~kg} ;{ }^{\text {a) }}$ Daily production per head is given according to [13] 
Quality of manure could be very variable, depending on the relation between excrements and litter, the way of production, livestock feed quality, kind of livestock, way of livestock keeping and care. Utilization of manure nutrients depends on contents of $\mathrm{N}, \mathrm{P}_{2} \mathrm{O}_{5}$ and $\mathrm{K}_{2} \mathrm{O}$, their accessibility for the plants. The contents of most important manure nutrients are caused by quality, but there are differences according to the experimental assessments of particular experts. Quantity of manure necessary for manuring depends, first of all, on the disposable manure quantity, type of soil, climate, crops, preceding crops, crop rotation, ploughing depth, etc. On the basis of manure production quantity per livestock head as well as the number of heads per particular categories, in Table 3 it is given the total annual manure production at the analyzed farm.

Table 3

Total annual quantity of manure for all animal heads on the farm

\begin{tabular}{lcccc}
\hline \hline Category of cattle & $\begin{array}{c}\text { Structural } \\
\text { unit }\end{array}$ & $\begin{array}{c}\text { Solid } \\
\text { phase } \\
(\mathrm{t})\end{array}$ & $\begin{array}{c}\text { Liquid } \\
\text { phase }\end{array}$ & Total \\
& & $(\mathrm{t})$ & $(\mathrm{t})$ \\
\hline Cows & 1.00 & 10.41 & 7.47 & 17.88 \\
Heifers in calf & 0.20 & $1.18^{*}$ & 0.85 & 2.03 \\
Heifers 12-22 months & 0.21 & 0.38 & 0.28 & 0.66 \\
Heifers 4-12 months & 0.22 & 0.52 & 0.37 & 0.89 \\
Female calves up to 4 monts & 0.22 & 0.10 & 0.19 & 0.28 \\
\hline Total per struct. unit of milking cow: & 12.59 & 9.16 & 21.74 \\
\cline { 1 - 2 } Fatt. cattle up to 250 kg & 0.66 & 0.64 & 0.46 & 1.10 \\
Fatt. cattle up to 450 kg & 0.66 & 1.89 & 1.36 & 3.25 \\
\hline
\end{tabular}

Per lines of cattle production (per head):

\begin{tabular}{lcccc}
\hline Milking cows keeping & 263 & $3,311^{* *}$ & 2,409 & 5,720 \\
Cattle fatten. up to $250 \mathrm{~kg}$ & 184 & $118^{* * *}$ & 84 & 202 \\
Cattle fatten. up to $450 \mathrm{~kg}$ & 184 & 348 & 250 & 598 \\
\hline Total annually & & $\mathbf{3 , 7 7 7}$ & 2,743 & 6,520 \\
\hline \hline
\end{tabular}

$* 1.18 \mathrm{t}=5.90 \mathrm{t} \times 0.20$ heads

$* * 3,311 \mathrm{t}=12.59 \mathrm{t} / \mathrm{head} \times 263$ heads

$* * * 118 \mathrm{t}=0.64 \mathrm{t} \times 184$ heads

Due to the gradual manure disassembling, the manure effect has been lasting for several years, depending on the soil and climate characteristics, ploughing depth and manuring normatives, culti- vation system. In light soils, manure disassembling is faster, so the effects are shorter, while in heavy soils it is disassembling slowly, so its effect is lasting longer. In some cases, there have been recorded positive effects of manure onto the yields even 10 years after its application. The most frequent practice is that manure basic values have been utilized for three years, i.e. $50 \%$ in the first year, $30 \%$ in the second year and $20 \%$ in the third one. Having in mind that there is no enough manure for manuring of all crops, it is necessary to use manure for those crops which have the best utilization of manure. Those are mostly root crops that a have long vegetative period. For example, in the crop rotation of present crops at the analyzed farm in the organic production conditions, it should be the best to use manure for the sugar beet and maize areas. In the second year small grains could be cultivated at the manured areas, while in the third year there should be leguminous crops (soybean, peas). Manuring norms per area unit differs by the crops (e.g. it is $23 \mathrm{t} / \mathrm{ha}$ in the case of sugar beet, $16 \mathrm{t} / \mathrm{ha}$ in the case of maize). In that way, an area of 200 ha should be manured in one year, while manuring of the same plot would be carried out each fourth year.

Having in mind the three-years effect of manure as well as the possibility that each year should be manured only $1 / 3$ of the total arable land area, by rotation of areas (by manuring a new area of 200 ha each year), manuring of the total arable area of 600 ha should be realized in the third year. Such a way of manuring is acceptable from the ecological aspect. From economic aspect, lower yields should be achieved, which should not be stimulative from the producers' profit aspect. However, the products got produced in the ecological production conditions which are of a high quality and in that way healthy-safe food is produced, so the producers' profit has been compensated through higher selling prices of such products. In that way, such production is economically justified as well.

However, the greatest problem facing with organic agricultural production is the fight against plant diseases and crop pests, as the chemical measures of fight are excluded, but with some exceptions. Consequently, the whole plant protection is based on the principle that problems from this domain should be prevented but not treated. In the organic production conditions, the plant protection should be organized in that way that 
damage by pathogenic organisms should be as low as possible. That is enabled by choice of species and sorts adapted to the habitat conditions, then to the proper crop rotation, by cultivation of postharvest, winter, associated crops or green manure crops. In the organic crop production system the crop rotation is realized as the phytosanitary measure which prevents appearance of some plant diseases, pests and weeds, but also has effect onto physical, chemical and biological improvement of soil. According to the researches done in the Netherlands, the crop rotation in the system of biological crop production should be multi-field (eight or ten field ones) because of the grass fields, because this system maintains soil fertility even without significant fertilizer utilization.

Table 4

Areas being manured according to the three-year system of manure utilization

\begin{tabular}{|c|c|c|c|c|c|c|c|c|c|}
\hline \multirow[t]{2}{*}{ Crop } & \multirow{2}{*}{$\begin{array}{l}\text { Area } \\
\text { (ha) }\end{array}$} & \multicolumn{3}{|c|}{$\begin{array}{l}\text { Year of manure } \\
\text { utilization }\end{array}$} & \multicolumn{3}{|c|}{$\begin{array}{l}\text { Area being manured per years } \\
\text { of manure utilization (ha) }\end{array}$} & \multicolumn{2}{|c|}{$\begin{array}{l}\text { Quantity of manure per particular } \\
\text { crops in the first year of manuring }\end{array}$} \\
\hline & & & & & 1st year & 2nd year & 3 rd year & $\mathrm{t} / \mathrm{ha}$ & Total (t) \\
\hline Winter wheat & 150 & - & 2 & 3 & - & 80 & 70 & - & - \\
\hline Winter barley & 30 & - & - & 3 & - & - & 30 & - & - \\
\hline Maize - grains & 58 & 1 & - & - & 58 & - & - & 16 & 928 \\
\hline Sugar beet & 90 & 1 & - & - & 90 & - & - & 23 & 2.070 \\
\hline Sunflower & 30 & - & - & 3 & - & - & 30 & - & - \\
\hline Soybean & 30 & - & - & 3 & - & - & 30 & - & - \\
\hline Silage maize & 122 & 1 & 2 & 3 & 22 & 90 & 10 & 15 & 329 \\
\hline Lucerne & 90 & 1 & 2 & 3 & 30 & 30 & 30 & 15 & 450 \\
\hline Oil rapeseed ${ }^{(\mathrm{a})}$ & 57 & - & - & 3 & - & - & 57 & - & - \\
\hline Peas+w. barl. ${ }^{(b)}$ & 33 & - & - & 3 & - & - & 33 & - & - \\
\hline TOTAL & & & & & 200 & 200 & 200 & & 3,777 \\
\hline
\end{tabular}

According to the scheme given by Boguslawski (1981), as well as some additions came from the practical experiences of Serbian experts for crop production and plant protection, it is given in the schematic presentation (Graph 1) of the crop rotation for the crops present in this model, in accordance with production orientation of the analyzed farm model in the organic production conditions.

Based on requirement toward the preceding crop, the tilled crops could be classified into several groups. As a rule, those are groups of crops where the similar agrotechnical measures have been applied and with similar requirements concerning preceding crop. These are the following plant groups: small grains, root crops, leguminous plants, oil and livestock feed crops. Appearance of diseases, pests and weeds can significantly reduce the preceding crop value in the case of each main crop. Each plant species is a bad preceding crop for the next crop, it supports spreading of common diseases. There are well-known examples of spreading the disease so-called flattening of small grains (Ophiobolus graminus), white decay (Sclerotinia spp.) in the case of sunflower, soybean and oil rapeseed, then appearance of the pests as follows: Agrotis spp., Tanymecus palliatus and Tanymecus dilaticollis, Elateridae, Meligethes aeneus Fabricius, Ostrinia nubilalis etc. It is not allowed to seed one after another those crops which have common diseases and pests. On the contrary, it is realized that favorable preceding crops are those which are pushing spreading of diseases and pests that should damage the next crop. For example, the perennial feed crops are pushing the mushroom which causes flattening of small grains. 


\begin{tabular}{|c|c|c|c|c|c|c|c|c|}
\hline \multirow[b]{2}{*}{ Crops } & \multicolumn{8}{|c|}{ Previous crops } \\
\hline & 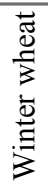 & 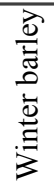 & 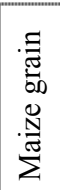 & 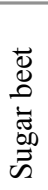 & $\begin{array}{l}\dot{\bar{D}} \\
\vdots \\
0 \\
\stackrel{c}{\leftrightarrows} \\
\Xi \\
\tilde{n}\end{array}$ & 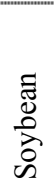 & 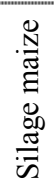 & 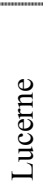 \\
\hline \multicolumn{9}{|c|}{ Winter wheat } \\
\hline \multicolumn{9}{|c|}{ Winter barley } \\
\hline \multicolumn{9}{|l|}{ Maize grain } \\
\hline \multicolumn{9}{|l|}{ Sugar beet } \\
\hline \multicolumn{9}{|l|}{ Sunflower } \\
\hline \multicolumn{9}{|l|}{ Soybean } \\
\hline \multicolumn{9}{|c|}{ Silage maize } \\
\hline \multicolumn{9}{|l|}{ Lucerne } \\
\hline $\begin{array}{l}\text { Regular } \\
\text { rotation }\end{array}$ & & & $\begin{array}{l}\text { op ro } \\
\text { ould }\end{array}$ & . & & & $\begin{array}{l}\text { egula } \\
\text { ation }\end{array}$ & \\
\hline
\end{tabular}

Graph 1. Scheme of the crop rotation on the farm in organic production conditions

(See more about that in Sredojević Zorica, 2000b)

In the case of the crop rotation composition within organic way of production, it should have in mind ability of some crops for atmospheric nitrogen fixation and soil enriching by this element. It is a very important share of leguminous plants in crop rotation and their influence on the order of crops. After leguminous plants there should be cultivated those plants that could have the best utilization of the increased nitrogen presence in the soil such as maize, silage maize, sugar beet etc.

Appropriate crop rotation gives numerous organizational, economic and ecological advantages, which are of great importance for the entire farm. Among them the following could be mentioned it has been provided necessary balancing between crop and livestock production, it has been facilitated management of heterogeneous crop production, it significantly facilitates composition of seeding plan for each year, as well as distribution of planned crops according to the place and the area of arable land, as places and areas for particular crop groups are defined in advance; it has been provided optimal rotation; there are given conditions for qualitative and timely carrying out of the key operations; there have been wiped out pathogenic agents of plant diseases, pests or weed plants in the most natural way and it has been enabled higher extent of plant feed. This also has ecological advantages, as it is avoided utilization of synthetic and chemical products for plant protection. In that way it has been disabled concentration of toxic agents both in soil and other environmental elements and in that way it has positive influence onto soil structure and highquality yields.

\section{CONCLUSION}

One of the basic differences between conventional and organic production is in the way of plant feeding, i.e. putting manure or fertilizer. It should strive for establishment of the combine-type farms with obligated livestock production, as in that way the problem of organic manure should be solved. By appreciation and accepting appropriate organic production advantages, it is for sure that many other items have to be foreseen and solved in order to apply organic production widely. It is necessary to find out sure nitrogen sources, to decrease negative effects of exaggerated chemization, to make a new generation of sorts and hybrides, to realize ideas of biological fight againts some harmful insects and weeds, as well as deseases, then to adapt mechanization, to change technology for plant cultivation. Besides achievement of higher selling (purchasing) prices for the product of organic origin, it is necessary appropriate agrarian policy measures to be taken over in order to make such production economically stimulative for the Serbian producers.

\section{REFERENCES}

[1] Chapin R. E,, Robbins W. A., et al. (2004): Off to good start: The influence of pre- and periconceptional exposures, parental fertility, and nutrition on children's health, Environ. Health Perspect, 112 (1), 69-78.

[2] Dimatteo K. (2006): Growth Prospects in the Organic Global Food Industry, Annual Meeting Organic Trade Association, Proceedings, 371-381.

[3] Flower B, et al. (2004): Cancer risk and parental pesticide application in children of Agricultural Health Study participants, Environ. Health Perspect, 112 (5), 631-635.

[4] Haring A. M. (2004): Policy support for organic farming in the European Union, $1^{\text {st }}$ International Congress on Organic Animal Production and Food Safety, 26-40.

[5] Hovi M. (2004): Animal Health and Welfare in Organic Livestock Production, $1^{\text {st }}$ International Congress on Organic Animal Production and Food Safety, 153-167. 
[6] Rahmann G. (2004): Organic animal husbandry in the European Union: standards, regulations and practice with special consideration of ruminants, $1^{\text {st }}$ International Congress on Organic Animal Production and Food Safety, 8-24.

[7] Sredojević, Zorica et al. (2000a): Regional aspects of agricultural production in the FR of Yugoslavia in the function of sustainable development, Volume 4, $7^{\text {th }}$ International Agriekonomic Scientific Days, Győngyős, $106-110$

[8] Sredojević, Zorica (2000b): Procena ekonomskih rezultata poljoprivrednog gazdinstva u uslovima alternaivnog načina proizvodnje, Poljoprivredni fakultet, Novi Sad.

[9] Sredojević, Zorica (2000): Ekonomski problemi ekološke poljoprivrede - monografija. Poljoprivredni fakultet, Beograd.
[10] Sredojević, Zorica et al. (2002): Economic Justification of Alternative Methods for Swine Liquid Manure Treatment, XXXV International Congress "Animal Sciences and Biotechnologies", Timisoara. Proceedings, Universitatea de Ştiințe Agricole şi Medicină, Veterinară a Banatului Timişoara. Facultatea de Zootehnie şi Biotehnologii, pp. 35-38.

[11] www.minpolj.sr.gov.yu/index.php? - Zakon o organskoj poljoprivredi - Pravilnik o metodama organske stočarske proizvodnje.

[12] Ruthenberg, H. (1958): Die Bestimmung der optimalen Aufwandshöhe und Aufwands-zusammensetzung bei der Mineraldüngung. Berichte über Landwirtschaft, 36 (1).

[13] Tietjen C., Vetter H. (1972): Einfluss von Abfällen und Ausscheidungen der tierischen Produktion auf Boden und Pflanze. Berichte über Landwirtschaft, 50. 650-665. 